\title{
New Public Management Reforms of the Danish and Swedish Welfare States: The Role of Different Social Democratic Responses
}

\section{CHRISTOFFER GREEN-PEDERSEN*}

This article investigates market-type reforms of the service welfare states in Sweden and Denmark. Sweden has implemented such reforms to a greater extent than Denmark. The explanation should be found in the different responses of the Social Democratic parties to the NPM agenda in general and market-type reforms in particular. In Denmark, the Social Democrats have opposed market-type reforms, whereas in Sweden they have been more open towards these ideas. With this focus, the paper differs from most other writings about variation in the extent of NPM.

\section{INTRODUCTION}

Within the last twenty years, the rich Organization for Economic Cooperation and Development (OECD) countries have been adjusting their models of welfare capitalism to a changed economic environment (cf. Scharpf and Schmidt). One type of adjustment has been reforms of the public sector, such as the introduction of explicit measures of performance, decentralization, private-sector styles of management, contracting out, and privatization. These reforms are generally known as the "New Public Management" (NPM) (Clark; Hood 1991; Rhodes).

The scholarly debate about NPM has increasingly been influenced by what Rune Premfors (1998, 145-146) labels the "structured pluralism story," focusing on variation in the extent to which different countries have implemented NPM reforms (e.g., Clark; Farnham et al.; Flynn and Strehl; Hood 1996; Kickert; Peters; Pollitt and Bouckaert; Pollitt and Summa). This is also the focus of this article. Its theoretical claim is that party politics, especially the responses of the Social Democrats to the NPM agenda, should receive more attention than is usually the case in the literature on NPM.

The empirical part of this paper provides an examination of the extent of market-type reforms of four welfare services in Denmark and Sweden: health care, care for the elderly, child care, and primary schools. The extent of market-type reforms is argued to have been greater in Sweden 
than in Denmark. Subsequently, the relationship of the differences in the responses of the Social Democratic parties in the two countries is shown. In Denmark, the Social Democrats (Sveriges socialdemokratiska arbetareparti-SAP) have opposed market-type reforms, whereas in Sweden, they have been more open towards these ideas.

The paper starts with a short overview of the NPM literature and the arguments put forward about variation in the extent of NPM reforms. It then develops a theoretical argument as to why party responses, especially the responses of the Social Democrats, should matter for the extent of NPM reforms. This is followed by a short discussion of the research design of the article. The next section offers a discussion of the extent of market-type reform in the four areas in the two countries. The paper continues with an outline of the NPM reform debate in the two countries, with special focus on the responses of the Social Democratic parties towards market-type reforms. The concluding section of the paper discusses the implication of the theoretical argument and the prospects for generalizing it.

\section{THE NPM DEBATE AND WHY SOCIAL DEMOCRATIC RESPONSES SHOULD MATTER}

As mentioned above, the scholarly debate about NPM has increasingly focused on the question of variation in the extent to which different countries have implemented NPM reforms. Four types of factors are normally discussed as explanations for variation (cf. Hood 1996; Olsen and Peters; Peters; Pollitt and Summa; Wright). The first group of arguments concerns macroeconomic factors. The macroeconomic troubles that hit the OECD countries in the 1970s are one of the reasons why NPM reforms have reached the political agenda in these countries. However, the extent of these troubles has varied across OECD countries. One hypothesis about NPM reforms would be that the countries that have faced the biggest macroeconomic troubles have implemented NPM reforms to the largest extent. The second group of arguments concerns party politics. NPM reforms are often seen as part of the neoliberal agenda of the 1980s. A second hypothesis about variation in NPM reforms would be that they have been implemented to a larger extent in countries and at times with right-wing governments. The third group relates variations to different administrative cultures stemming from different "state traditions." Guy Peters (1997) contends that the Anglo-American tradition is more receptive to market-type reforms than is the case in the Germanic tradition in particular (cf. also Clark; Loughlin and Peters; Rhodes). The fourth group of arguments relates variation to different political institutions. These may be found at two levels. First, macroinstitutional differences, such as majoritarian versus consensus systems, may result in different magnitudes of NPM reforms (cf. Barlow et al.; Pollitt and Summa; Yesilkagit and de Vries). Second, differences may be due to microinstitutional 
differences. For instance, Peter Christiansen points to the power of public sector unions as part of the explanation for the limited extent of markettype reforms in Denmark. As made by Jørgen Christensen and Thomas Pallesen, the argument about microinstitutional structures can also be used to explain differences in the extent to which various types of NPM ideas are implemented.

In addition to the focus on the responses of the Social Democratic parties, this article argues that NPM reforms should be seen within a broader context of welfare-state reforms, whereas in most NPM reform literature, they are analyzed as public administration reforms. However, when it comes to reforms such as the introduction of quasimarkets in the health-care sector or private providers of care for the elderly, NPM reforms become part of the political battle over the welfare state.

The need to analyze NPM reforms within a welfare-state context is particularly urgent when dealing with the Scandinavian countries. The literature on different welfare-state regimes (Esping-Andersen 1990, 1999; Huber and Stephens 2000) has documented considerable differences among countries in the provision of social services such as care for the elderly and child care. In Scandinavia, there is an extensive range of publicly funded and provided social services. The public sectors there include the extensive service welfare states. Therefore, public sector reforms must here be analyzed within a broader welfare-state context.

In the wake of Pierson's (1994, 1996) seminal work, welfare-state retrenchment-or reforms-has attracted a lot of scholarly interest. This debate has been detached from the debate about NPM reforms, and with a few exceptions (e.g., Clayton and Pontusson; Timonen) it has paid little attention to welfare services. As argued by Ross (2000b), the debate has also not paid much attention to party politics, yet a number of studies have recently done so (Green-Pedersen 2001; Kitschelt; Ross 2000a). Furthermore, these studies emphasize partisan effects to be more complex than implied by the argument that welfare-state retrenchment is the result of right-wing incumbency. The theoretical aim of this paper is to show that the recently developed arguments about partisan politics and welfare-state retrenchment are also relevant for the understanding of variation in NPM reforms.

The starting point for the argument about partisan effects is the literature on agenda-setting, especially framing of political issues (Riker; Sheingate). The issue of NPM reforms can be framed in rather different ways, with important consequences for their political attractiveness. Opponents of NPM reforms can be expected to portray such reforms as part of a neoliberal attempt to dismantle the welfare state, and to argue that they are just a disguise for cutbacks in the welfare state and will result in a decreasing quality of public services. Proponents of NPM reforms will argue that they lead to more efficient service provision, and thus the possibility of offering services of the same quality but at lower cost or better services at the same cost. Proponents will also try to argue that 
NPM reforms form a way of fighting a bureaucratic "nanny state" - for instance, by providing consumers with a greater choice of services. For politicians, the attractiveness of NPM reforms depends very much on the possibilities of framing such reforms in the latter way. If introducing NPM reforms will be seen by the electorate as an attempt to provide citizens with better and cheaper services as well as more choices, politicians may find them attractive. If such reforms are seen as part of an ideological attack on the cherished welfare state, they invoke the politics of blame avoidance (Pierson 1994; Weaver). In addition, the formative moment of the NPM debate is important because, as argued by the agenda-setting literature (cf. Baumgartner and Jones), issue definitions tend to be stable over long periods of time.

The question, then, is one of what determines the way the NPM issue is framed. Right-wing parties can be expected to be proponents of NPM reforms. Whereas it is very difficult for right-wing parties to justify welfare-state retrenchments except in times of severe economic crisis (Green-Pedersen 2000), NPM reforms seem to offer such parties better chances of a positive framing. The parties can argue that they aim at a better welfare state, not a leaner one. However, right-wing parties are crucially dependent on the strategy of the Social Democratic parties.

Using the idea of issue ownership or issue association (Budge and Farlie; Ross 2000a), one may argue that the welfare-state issue is owned by Social Democratic parties in the sense that the electorate sees Social Democratic parties as the true proponents of the welfare state. Right-wing parties are seen as more preoccupied with keeping down taxation and managing the economy. If Social Democratic parties oppose NPM reforms as an ideological attack on the welfare state, right-wing parties will find it very hard to portray NPM reforms along positive lines. On the other hand, if Social Democratic parties embrace NPM reforms as a way of renewing and improving the welfare state, a consensus around a positive NPM story may emerge, making the implementation of such reforms much more attractive. The next question concerns which factors determine the response of the Social Democratic parties. One important factor is whether they are in government or opposition. In government, Social Democratic parties are held responsible for the problems of the public sector and the promise of cheaper and better service included in the NPM agenda may be attractive. In opposition, the NPM agenda can be opposed without necessarily having to come up with very well specified alternatives.

Summing up, the theoretical argument is that the response of Social Democratic owners of the welfare state is crucial because it determines whether NPM reforms are framed in a way that makes them politically attractive to implement. Furthermore, the position of the Social Democratic parties at the formative moments is important, since issue definitions tend to be "locked in." ${ }^{2}$ If Social Democratic parties have once embraced NPM reforms positively, they will find it hard to change to a 
negative response. Finally, whether the Social Democrats are in government or opposition at the formative moment can be expected to influence their response strongly.

\section{RESEARCH DESIGN}

Having outlined the theoretical argument of the paper, I can now defend the choice of Denmark and Sweden as the two cases for investigation. Both countries are prime examples of the Scandinavian service welfare states (Huber and Stephens 2000), and the public sector in the two countries is thus basically the same (cf. Lane). The implication of this is that the microinstitutions in the two countries are largely similar. For example, both countries have very strong public sector unions. The macropolitical institutions are also largely similar, just as both countries belong to the Scandinavian administrative culture (Loughlin and Peters). Finally, in both countries, the welfare state has faced dire economic straits within the last twenty years, although the development over time has been somewhat different. In Denmark, the economy was "at the brink of the abyss" in the early 1980s, then recovered somewhat in the 1980s and early 1990s before doing very well in the last part of the 1990s (Nannestad and GreenPedersen). The Swedish economy did somewhat better than the Danish in the 1970s and 1980s; it then witnessed a meltdown in the beginning of the 1990s, from which it has recovered quite quickly (Hemerijck and Schludi). Altogether, most theoretical arguments about NPM reforms would not predict any difference in the extent of NPM reforms between Denmark and Sweden.

However, arguments about party politics would predict such difference. Arguments linking NPM reforms with right-wing incumbency would predict Denmark to have gone farther in terms of NPM reforms. The reason is that Denmark had nonsocialist governments from 1982 to 1993, whereas the nonsocialist government in Sweden from 1991 to 1994 has been the only such government since 1982. The theoretical argument about the response of the Social Democrats would predict just the opposite. In both countries, the welfare-state issue is clearly owned by the Social Democratic parties, yet as will be argued below, the Social Democratic parties in the two countries have found themselves in different political situations and have responded differently to the question of NPM reforms.

Before turning to the empirical part of the paper, two further questions must be discussed. The first one is the definition of market-type reforms. Following Pollitt and Summa, it is useful to distinguish between different dimensions of the NPM agenda. One such dimension is marketization, or what the OECD (11) describes as "market-type reforms." The gist of this dimension is the introduction of the characteristics of a marketmost importantly competition, but also pricing-into the public sector. Examples of such reforms include contracting out, free choice of provider, 
internal markets, user fees, and privatizations (cf. Hansen; Pollitt, and Summa, 8; OECD). Thus, the reforms studied in the following sections do not include, for instance, decentralization or user influence in the form of user boards. The reason for focusing on market-type reforms of welfare services is that this is often the most controversial part of the NPM agenda and is thus an area where the effects of party politics should be visible. Finally, I focus on the introduction of market-type reforms in four core welfare services: health care, care for the elderly, child care, and primary schools.

The second question relates to the role of local governments in the provision of welfare services in Scandinavia. Counties and municipalities organize the services, often quite independently of central government (Albæk, Rose, Strömberg, and Ståhlberg). In other words, if market-type reforms have been introduced in Denmark and Sweden, local governments will often have introduced them. Nevertheless, the argument of this paper is that the political struggles at the national level have been crucial.

There are two ways in which the national level influences the local level. First, the local level organizes the services within a national legislative framework, and this framework may, for example, preclude contracting out. Second, the political debate and framing of the NPM issue largely takes place at the national level. Each county and municipality in Scandinavia is part of the countrywide debate, not an independent political system. These two avenues of influence constitute necessary conditions for the enactment of market-type reforms in local governments. This is obvious in relation to national legislation, but is also the case in relation to the national debate. By way of example, even though national legislation may permit contracting out, local politicians are only expected to be willing to contract out if the debate taking place at the national level has framed the issue along positive lines.

\section{MARKET-TYPE REFORMS OF WELFARE SERVICES IN DENMARK AND SWEDEN}

In the following, the extent of market reforms in the four service areas will be discussed area by area. The extent of market-type reforms will be evaluated by looking at political decisions made by either the national government or local governments-that is, political outputs. An evaluation of the extent of market reforms could also have included outcomes. In relation to, for instance, free choice for the users, whether or not such choices actually imply competition is dependent upon the users' actual utilization of the free choices. Nevertheless, outcomes in this sense are not included because the above argument is not meant to explain, for instance, user behavior, even though it may be extended to do so. Furthermore, focus in the following is on reforms - that is, changes in a market-oriented direction. However, questions about the market charac- 
teristics present in the services before the NPM debate cannot be ignored, since, in some areas, the two countries had different starting points likely to affect the possible reforms.

\section{The Health-Care Sector}

Both Denmark and Sweden are examples of the public, integrated model of health care, in which services are financed through general taxation and publicly provided. Furthermore, in both countries health care is decentralized, as the responsibility for provision is placed with the counties. Nonetheless, some differences exist. Denmark has a family doctor system under which patients are allowed to choose their own doctor and doctors are self-employed. However, competition is very limited since the government regulates the number of general practitioners. Sweden has no family doctor system, and general practitioners are public employees. Furthermore, patients had no free choice of primary health care. In Sweden, limited user fees for primary care and for hospital visits have existed for a long time, whereas in Denmark these services are free of charge (Saltman and Figueras). ${ }^{3}$

In Sweden, the health-care sector reform process began in the 1980s with other types of NPM reforms, such as the delegation of financial responsibility to individual hospitals and the introduction of global budgets (Anell; Anell and Svarvar; Diderichsen). Market-oriented reforms, introduced in the 1990s, can be divided into three types: splitting providers and purchasers; free choice for the patients; and reforms of primary health care, including more room for private alternatives (cf. Blomqvist and Rothstein, 192-198).

The general idea behind splitting providers and purchasers is that boards with political representation buy health-care services from providers who, even though they are still public, compete with each other. Today, the majority of Swedish counties have split the provider and purchaser role (SOU, 146). The number of boards in each county buying health-care services varies from one to around fifteen (Anell; Anell and Svarvar; Rehnberg).

Before 1991, Swedish patients had no right to choose either hospital or primary care. This has changed. All Swedish counties now allow a free choice of primary care, and most of them also offer free choice of hospital, including hospitals in other counties (Anell). The possibilities of choosing health care without referral varies across counties, but in a number of counties the possibilities have become quite extensive (Svensson and Nordling). In 1994, patients were also given the right to choose a family doctor, private or public, but this system was abolished again when the Social Democrats regained power (Blomqvist; Rehnberg).

Private practitioners have also gained a stronger foothold in primary health care. There have always been a few private practitioners in major cities, and at the beginning of 1994 the nonsocialist government intro- 
duced the free right of private practitioners to establish themselves. As patients were guaranteed public reimbursement, competition was thus introduced in primary health care. Upon return to government, the Social Democrats also reversed this reform, but allowed the already-established private practitioners to continue their service (Blomqvist; Rehnberg).

In Denmark, other types of NPM reforms, such as the delegations of financial authority and global budgets, have also been introduced (Christensen and Pallesen; Pallesen). However, most market-type reforms have been very limited (Jespersen). Provider/purchaser models have not become common, the organization of the primary health-care sector has remained largely unchanged, and user fees, in areas where they exist in Sweden, have hardly been discussed. Furthermore, visiting a hospital or specialist without a referral from a general practitioner is still largely impossible in Denmark (cf. Pallesen and Pedersen; Vrangbæk 1999). The only significant market-type reform of Danish health care is the right in principle of the patient to choose a hospital in a different county, introduced by national legislation in 1992. However, since the counties decide for themselves how hospitals are paid for patients from a different county, and since a hospital can reject a patient from another county, the right of the patient is limited in practice, though it is not without content (Vrangbæk 2000). In summary, as argued by Thomas Pallesen and Lars Pedersen, if the Danish health-care system is unique, that uniqueness has to do with the lack of reforms.

Comparing market-oriented health-care reforms in the two countries, as argued by Sahlin-Andersson (301), Sweden has gone further than Denmark. This difference is most obvious in the hospital sector. User fees in Swedish health care also increased during the 1990s, when the counties were given more freedom to decide the level of fees (SOU, 146). Sweden has introduced market-type reforms in primary care, but some of the conditions introduced in Sweden have long existed in Denmark. Obviously, the Swedish reforms do not represent a revolution of the health-care system (cf. Anell). Yet, as argued by, for instance, Claus Rehnberg and Paula Blomqvist, the reforms in Sweden have been substantial, which is not the case in Denmark.

\section{Care for the Elderly}

The Swedish and the Danish welfare states offer extensive care for the elderly in the form of home help, residential homes, and sheltered housing. Traditionally, a decentralized, public, integrated model has also dominated care for the elderly in both countries. Local governments have provided the care, financing this out of general taxation. ${ }^{4}$ In the 1990s, Sweden took some steps away from the model, which did not happen in Denmark.

In 1992, a reform of Swedish care for the elderly, "Ädelreformen," transferred care for the elderly from the counties to the municipalities. 
Since then, the municipalities have implemented market-type reforms of two kinds (Szebehely). First, today the majority of Swedish municipalities have implemented the same kinds of provider and purchaser reforms as the counties have done in health care (Socialstyrelsen 1999b; SOU, 174-175). Second, an increasing number of Swedish counties have started buying care from private firms. In 1999, 9 percent of the Swedish elderly were cared for by a private firm, compared to 3.5 percent in 1993 (Socialstyrelsen 1999b, 7). Municipalities either contract out the whole operation of residential homes, home help, or sheltered housing or buy places in institutions set up by private providers. ${ }^{5}$ In 1999, around 25 percent of the Swedish municipalities had contracted out part of the operation of home help, residential homes, or sheltered housing to private firms, including all municipalities with more than 100,000 inhabitants (KommunAktuellt Direkt; Socialstyrelsen 1999b, 26-28). Around 40 percent of the municipalities bought places in institutions set up by private providers (Socialstyrelsen 1999b, 34-35). These figures do not indicate that private firms have taken over Swedish care for the elderly, but they do suggest that such firms have gained an increasing foothold. Today, several major private firms operate within Swedish care for the elderly, with a financial turnover of several hundred million Swedish kroner (KommunAktuellt Direkt; Socialstyrelsen 1999b).

In Denmark, the organization of care for the elderly is more or less unchanged. There are examples of contracting out of home help and residential homes, as well as models in which the elderly have been offered the choice between public and private providers, but these examples number relatively few (Bertelsen 2000; Det Kommunale Kartel Organisationsafdelingen; Institut for Serviceudvikling; Kommunernes Landsforening). Purchaser provider models are also largely unknown within Danish care for the elderly (Institut for Serviceudvikling). All together, market-type reforms of the Danish care for the elderly sector amount to a couple of cases of contracting out that received a lot of public attention, but the market has not gained a real foothold there. Finally, home help is still mainly free of charge, whereas user fees in the Swedish system of care for the elderly have been increasing (Socialstyrelsen 1999a; Szebehely).

Summing up, market-oriented reforms of care for the elderly are more extensive in Sweden than in Denmark. This does not mean that a revolution has happened in Swedish care for the elderly, but market-type reforms have been implemented in many Swedish municipalities, which is not the case in Denmark.

\section{Child Care}

As with other welfare services, the responsibility of child care has been decentralized to the municipalities, which finance child care out of general taxation. However, in both countries significant user fees exist, varying 
from municipality to municipality. Care is traditionally provided in public institutions or by registered child-minders in their private homes. ${ }^{6}$

In Denmark, market-type reforms of child care were discussed from 1982 on. After a long and intense debate, an amendment to the Social Service Act was passed in 1990, paving the way for the municipalities to give financial support to private persons or organizations providing child care outside the organizational framework of the municipalities and thus introducing competition (Damgaard 1997; Damgaard 1998, chapter 6). However, only a limited number of these "pool schemes" have been established, caring for only around 2 percent of the children in 1999, and the figure is not increasing (Danmarks Statistik 1997, 5, 15; Danmarks Statistik 2000a, 12, 19). ${ }^{7}$ Furthermore, the new Social Service Act passed in 1997 has allowed contracting out of child-care institutions (Borchorst), but very few examples of this can be found (BUPL; Kommunernes Landsforening). In sum, market-type reforms of Danish child-care services have been very limited.

In Sweden, the possibility of nonpublic provision of child care was introduced in the 1980s. Until 1992, only nonprofit providers were allowed, but in 1992, the municipalities were allowed to support child care provided by profit-maximizing firms (Montin 1992; Montin and Elander). In the 1980s, the Swedish municipalities did not make much use of the new possibilities (Montin 1992), but in the 1990s, alternative provision increased significantly. Thus, in 199913 percent of Swedish children younger than six being cared for received care from a private provider (Skolverket 2000a, 12-16). In around half of the cases, parents' associations organize private provision. ${ }^{8}$ Private profit-maximizing firms constitute around 25 percent of the cases (Skolverket 2000b, 23).

Comparing the experience of the two countries in child care, markettype reforms have been more widespread in this field in Sweden. For instance, where less than ten examples of child care run by private firms can be found in Denmark (BUPL), in 1999 Sweden had 278 child-care institutions run by private profit-maximizing firms (Skolverket 2000b, 23). As in other service areas, user fees in Swedish child care have been increasing, which is not the case in Denmark (Lehto, Moss, and Rostgaard). Again, what has happened in Sweden is not a revolution, but, as in care for the elderly, market-type reforms have gained an increasing foothold.

\section{Primary Schools}

Primary schools constitute the area of services in which the historical differences between Denmark and Sweden are the greatest (Lindbom 1998). Both countries have public and tax-financed school systems, but the historical role of private or independent schools is different. Unlike the case in Sweden, such schools have a long tradition in Denmark. Private schools in Denmark are financially dependent on public support, as the user fees 
only cover around 15 percent of the operating costs (Christiansen) and the schools have to abide by government regulation concerning tests and so on (Christensen 2000, 200). However, they do constitute an element of competition. ${ }^{9}$ Almost no market-type reforms of Danish primary schools have taken place. For instance, Danish parents' opportunities to choose a different public school from the one allocated to them by the municipality still remain very limited in practice (Christensen 2000).

As in other areas, the reforms of Swedish primary schools started in the 1980s with other NPM reforms such as decentralization. The municipalities gained much more influence on primary schools, as they have always had in Denmark (Lidström and Hudson; Lindbom 1995, 64-74). In principle, Swedish parents were also given the right to choose which public school their children should attend (Lidström, 139). In the 1990s, the Swedish primary school system witnessed other market-type reforms. In 1992, the nonsocialist government introduced a voucher system giving parents the right to choose between public and private schools. If the parents chose a private school, the voucher had the value of 85 percent of the average costs for a pupil in a public school. In 1993, private schools were also given the opportunity to charge reasonable user fees. However, after the Swedish Social Democrats returned to government power, they abolished this possibility. They also decreased the value of the voucher to 75 percent of the public costs, but from 1996 on, the law stipulated that the voucher should correspond to the costs per pupil in public schools (Blomqvist and Rothstein, 162-165; Lidström and Hudson, 19-25). Some Swedish municipalities have responded to the national regulation by both promoting independent schools and stimulating parents to actively choose between schools. However, the number of municipalities practicing this approach decreased towards the end of the 1990s compared to the beginning of the decade (Lidström).

Comparing the two countries in the primary-school area is more difficult than in other areas because of their different starting points. Markettype reforms have been introduced in the Swedish primary school system, mainly by introducing competition through the support for private schools. In Denmark, hardly any market-type reforms have been introduced, but competition from private schools has long existed. ${ }^{10}$

\section{The Four Areas Seen as One}

When looking at the four areas discussed above as a whole, it is apparent that market-type reforms have been more extensive in Sweden than in Denmark. This conclusion about the direction of change holds true for all four areas discussed. However, in two cases, private schools and the right to choose primary care, the changes in Sweden have brought the country to the point where Denmark has been for a long time.

The report of the government commission investigating the current state of the Swedish welfare state (Kommitté Välfärdsbokslut) describes 
the 1990s as the "decade of the market" in relation to welfare services (SOU, 178-184). As explained above, stating that a revolution has taken place in Sweden would be to overstate the case, but, as argued by Torsten Svensson (144-163), market-type reforms have gained an increasing foothold in the Swedish welfare state. This is not the case in Denmark, where the analysis confirms Peter Christiansen's conclusion that the idea of market solutions to problems of public sector governance was a "prescription rejected."

\section{DIFFERENT RESPONSES OF THE SOCIAL DEMOCRATIC PARTIES}

As explained above, the theoretical argument of this paper claims that differences in the extent to which countries have implemented NPM reforms have been influenced by the differing responses of the Social Democratic parties. Thus, in the following, the first aim is to show that the responses of the Social Democratic parties in Denmark and Sweden have differed and how this has caused a different debate in the two countries. The second aim is to discuss the reasons for the different responses.

In Denmark, the "formative moment" in the debate about the question of welfare-state reforms including NPM reforms was the coming to power of a nonsocialist government in 1982. The Danish economy was at the "brink of the abyss," and the new government launched a comprehensive "crisis solution" containing a privatization program implying market-type reforms (Greve; Kristensen 1987, 1988). Like most other elements in the crisis solution, the privatization program met stiff resistance from the Social Democrats and the trade unions. The general opposition strategy of the Social Democrats was to attack the new government by portraying its policies as an ideological attack on the welfare state (cf. Green-Pedersen 2000, chapter 9). This was also the response to the privatization program. As the Social Democratic spokesman put it in a debate in the Danish parliament: "We do not perceive privatization as an endeavor to achieve greater efficiency, but as an endeavor to cut back by creating inequality. It runs contrary to our perception of human nature, and so we will reveal and fight such endeavors to put the clock back" (quoted in Kristensen 1988, 13). As argued by Ole Kristensen (1988, 13-14), the Social Democrats were successful in establishing the premises of the debate along the lines of characterizing privatization as a basic attack on the welfare state, and the privatization program was dead before it started (cf. also Greve, 37-38). After this failure, the government launched a much more modest "modernization program," but this also largely failed (Christensen 1991). As exemplified by the attempts of market-type reforms of child care, strong political resistance from the Social Democrats and the trade unions made the implementation of such ideas politically very difficult (Damgaard 1997). In most cases, the nonsocialist governments put market-type proposals back in the drawer, as 
the Prime Minister literally did with a privatization proposal from his own party in 1983 (Dyremose).

In 1993, a Social Democratic-led government took over, and such governments ruled Denmark until the end of 2001. In other areas of the welfare state (cf. Green-Pedersen 2000), a "Nixon goes to China" dynamic (Ross 2000a) has been visible, in the sense that the Social Democratic-led governments have implemented proposals that were politically impossible for the nonsocialist governments. Such tendencies have also been visible in relation to reforms such as privatization of telecommunications and corporatizations (Christensen and Pallesen forthcoming).

However, in relation to market-type reforms of welfare services, the situation of the Danish Social Democrats has proved rather difficult. The leadership of the party has tried to establish a more pragmatic line within the party. By way of example, on two occasions it has tried to persuade the rest of the party, including local politicians, to pursue a more pragmatic line towards contracting out. In both cases, however, the leadership has lost the battle (Bille). As mentioned earlier, national legislation has also opened up for contracting out of child care, without the municipalities actually making use of the opportunities. The problem for the leadership of the Danish Social Democrats is that they are locked into their own rhetoric from the 1980s. As they successfully defined market-type reforms as an ideological crusade against the welfare state, it has proved impossible to persuade the rest of the party-and the public — that such reforms are now a tool to achieve cheaper and/or better service. Thus, the official line of the party is still the one found in the working program from 1996 (Socialdemokratiet i Danmark) stating that the provision of welfare services should remain a public task.

In Sweden, the "formative moment" of the debate about NPM reforms was also a shift of government in 1982. Here, however, the Social Democrats came back into power. The SAP had long felt vulnerable to attacks from the nonsocialist parties for having created a bureaucratic nanny state and partly interpreted the six preceding years out of power as a sign that this criticism had the support of the electorate in Sweden. The new Social Democratic government, therefore, put publicsector reforms on top of its agenda and launched a special "public administration policy," including a ministry to take care of the issue (Gustafsson; Pierre; Premfors 1991). In other words, the SAP admitted the need for changes in the Swedish public sector. However, the means suggested by the SAP in 1982 were not market-type reforms but other NPM reforms, such as decentralization and a more service-oriented welfare state. The SAP's idea was that such reforms would prevent more market-type reforms from reaching the political agenda (Antman, 36). As exemplified by the ban on profitmaximizing firms in child care, the SAP generally rejected markettype reforms with arguments very similar to those of the Danish Social Democrats (Rothstein, 501-505). 
However, during the 1980s, there was growing criticism from within the SAP that the government was not doing enough to reform the Swedish public sector (Antman, 38-42). The public administration policy launched in 1982 did not take the wind out of this criticism of the public sector. After the 1988 election, the debate intensified, and the Social Democrats started to abandon their rejection of market-type reforms (Hadenius and Nilsson). In relation to, for instance, primary schools, the SAP now accepted the basic content of the nonsocialist parties' suggestions (Schüllerqvist). In the Budget Bill for 1990, the party gave up its principal reservations against market-type reforms of welfare services (Premfors 1998). The SAP was certainly not united on this issue, but, at least for a while, the promarket wing of the party, centered around the powerful Minister of Finance Kjell-Oluf Feldt, came to represent the party line on the issue (Premfors 1991).

In 1991, SAP suffered a historic defeat in the election, which paved the way for a nonsocialist government. At the same time, the Swedish economy experienced a meltdown. This situation opened a window of opportunity for the nonsocialist parties. The Social Democrats had already admitted that the Swedish welfare state needed to be reformed in a market-oriented way, and the economic crisis added fuel to this fire. Thus, the nonsocialist parties implemented more radical market-type reforms. The SAP protested against many of these reforms, and when the party regained power in 1994, it reversed, for example, parts of the reforms concerning health care and primary schools. However, the Social Democrats have continued to pursue public sector reforms (Premfors 1998; Svensson). Thus, as a number of authors argue (e.g., Antman, 44-45; Blomqvist; Håkansson, 60; Montin 1997, 264), the market-type reforms implemented by the nonsocialist government from 1991 to 1994 followed a path that had been laid out by the Social Democrats. The latter had admitted that the public sector was "part of the problem, not the solution," as Antman (20) put it. Reverting to a position similar to that of the Danish Social Democrats was no longer possible. Thus, despite continuing internal disagreement within the SAP (cf. Blomqvist and Rothstein, 9-12), the party no longer opposes the existence of private providers of, for instance, child care and care for the elderly in the same way as does their Danish counterpart. ${ }^{11}$ However, the SAP has strongly contested a further radicalization of the market-reform agenda in the case of an attempt to privatize a hospital in the Stockholm region (Svensson).

Summing up, the Swedish debate about NPM reforms proceeded along different lines than did the Danish debate. In Sweden, the debate became one concerning reforming an ineffective welfare state, leaving little choice for the citizens (cf. Boréus, 263-265; Rothstein). In office, the SAP had to respond to this criticism, and, despite internal disagreement, market-type reforms were gradually accepted and defined as a way of providing better and cheaper services. Once this had happened, even opposing more radical market-type reforms proved very difficult politically. As argued 
by Evelyne Huber and John Stephens (2001, 246-248), for once the SAP actually lost a debate about the welfare state in Sweden. In Denmark, the Social Democrats in opposition strongly opposed market-type reforms. Once in government, the party-leadership tried to achieve a more pragmatic line, but without success.

The question, then, is one of why the responses of the Social Democratic parties have differed. Was it simply an effect of the Danish party being in opposition and the Swedish being in government when the NPM agenda emerged? To some extent, this is the case. Because the SAP was in government, the problems of the public sector in Sweden became its problems. In Denmark, the problems of the public sector were not the problems of the Social Democrats before they regained office in 1993. Therefore, the SAP could not simply reject the NPM-agenda. Yet additional factors have probably played a role. The Swedish Social Democrats have dominated government more than their Danish counterparts have done, and their ownership of the welfare-state issue is thus stronger. Therefore, problems of the welfare state in Sweden are problems of the Social Democrats to a larger extent than is the case in Denmark. Furthermore, because Denmark already had elements of choice as well as a more decentralized public sector (Lindbom 1995; cf. also Knudsen and Rothstein), criticizing the Danish welfare state for being paternalistic and leaving no choices for citizens was more difficult. For instance, key elements in the nonsocialist criticism of the Swedish public sector included the lack of choice in relation to primary schools and primary care. In Denmark, citizens have had such choices for a long time.

Before I turn to the conclusion, two theoretical points deserve some further comments in the light of the two cases. The first point relates to the role of local governments. Local governments have enacted many of the Swedish reforms. Nonetheless, as mentioned above, this paper's argument centers around the national level because the political debate about market-type reforms is a national debate. However, this does not imply that looking in more detail at the local level is unimportant. In Sweden, not all local governments have pursued market-type reforms, and a few have done so even in Denmark. In other words, there is variation at the local level for which this article does not account. A number of other studies have already investigated this question (Bertelsen 2001 and Christoffersen and Paldam on Denmark; Lidström and Montin on Sweden), and none of these studies find market-type reforms to be something particular to counties and municipalities governed by nonsocialist parties. Still, in both countries some of the more radical reforms, such as the privatization of the hospital in the Stockholm area and the few examples of contracting out of care for the elderly in Denmark, have been enacted by nonsocialist local governments. Altogether, studying the local level is clearly relevant. The danger of focusing on this level is that factors working at the national level are ignored and differences between countries are never recognized. 
Finally, the role of economic crisis in the two countries deserves a few words. Could the reforms implemented in Sweden be explained by the country's economic crisis? The crisis put strong financial pressure on the local governments (Timonen), and their willingness to implement market-type reforms could be interpreted simply as a response to the financial pressure. However, Danish local governments existed under similarly strong financial pressure in the 1980s (Blom-Hansen and Pallesen) without implementing market-type reforms. The meltdown of the Swedish economy in the beginning of the 1990s clearly added fuel to the criticism of the public sector. Still, comparison with Denmark, which had its economic crisis in the beginning of the 1980s, shows that such crisis only led to market-type reforms because they had already been defined as a way of achieving better or cheaper services and not as an ideological attack on the basic idea of a welfare state.

\section{CONCLUSION}

Put briefly, in order to understand why countries implement NPM reforms to a different extent, the responses of the Social Democratic parties must be taken into account. The differing responses of the Danish and Swedish Social Democrats explain why market-type reforms of welfare services are more widespread in Sweden than in Denmark. In this concluding section, a number of implications of this argument will be discussed, as will the prospects of generalizing the argument.

The first implication of the argument is that the literature on NPM reforms should pay more attention to party politics. As explained above, most other scholarly writings about NPM have focused on various political institutions, economic troubles, and administrative traditions. However, the impact of party politics is more complicated than seeing NPM reforms as an initiative by right-wing parties. Looking at the Swedish case in isolation may support such an argument, because from 1991 to 1994 the right-wing government implemented several important market-type reforms. However, once the Swedish development is compared to Danish, such an argument becomes much less convincing. The coming to power of the right-wing government in Denmark in 1982 should have been expected to initiate reforms paralleling those of the Swedish government from 1991 to 1994. One needs to look at the responses of the Social Democratic parties in the two countries to understand the differences. In this way, the argument of this paper parallels an argument made in relation to retrenchment of transfers (Green-Pedersen 2001) that studying party competition is important for understanding variation in welfare-state reforms.

Further, it should be noted that the implication of the argument of this paper is not that it is easy to implement welfare-state reforms. Paul Pierson (1994) has put forward a number of plausible arguments 
as to why welfare-state retrenchment is the politics of blame avoidance. Christensen and Pallesen (2001) and Christiansen have pointed to factors such as resistance from public employees and risk-adverse and control-maximizing politicians that make NPM reforms-especially market-type reforms-politically dangerous. These arguments about the politics of reform are plausible. However, it is important that they do not prohibit a search for the political conditions under which reforms can take place, such as the one conducted in this article (cf. also Sheingate).

Another implication of this article is that NPM reforms should not just be studied as public administration reforms; they must be seen within the broader context of welfare-state reforms. In both Denmark and Sweden, such an approach is necessary in order to understand the different responses of the Social Democratic parties in the two countries. The importance of this implication varies depending on the type of NPM reforms studied. Some NPM reforms, such as reforms of management principles and pay systems, are reasonable to study as public administration reforms because they do not normally attract the same kind of attention from political parties as do welfare-state reforms.

The developments in the two countries are also interesting in light of the increasing political-science interest in policy legacies and path dependency (Giamo and Manow; Pierson 2000) that is implicit in the arguments about the impact of administrative or state traditions. Such arguments would have predicted that the prior existence of some market characteristics in Denmark - such as, for instance, private schools-would have made the country more receptive to market-type reforms. This has proved false, and the reason has to do with the opportunities for framing the political debate available to the political parties. Through this, the policy legacy has been important, but in a different way from what is expected by usual path-dependency logic.

The final question to be addressed concerns generalizing the argument to other countries. In this regard, it is important to be aware that a focus on market-type reforms of welfare services is less obvious outside Scandinavia, where such services are less extensive and often organized in different ways. Yet the theoretical argument of this paper is not necessarily restricted to market-type reforms of welfare services, and it should be applicable to non-Scandinavian cases as well. The most promising cases for generalization are probably the Antipodes. In Australia, and particularly in New Zealand, a wave of NPM reforms has already been set in motion by 1980s labor governments. Thus, both countries-especially New Zealand-have come to stand in the vanguard of NPM reforms. Perhaps this development has something to do with the fact that labor governments ruled when NPM ideas came on the political agenda and responded positively to many of them (Castles, Gerritsen, and Vowles; Denemark; Schwartz). 


\section{ACKNOWLEDGMENTS}

An earlier version of this paper was presented at the 2001 SOG conference at the University of Oklahoma. Thanks to the participants for their comments and suggestions. The paper has also been presented to the public policy and public administration units at the Department of Political Science, University of Aarhus. Thanks to all the members and in particular Jørgen Grønnegård Christensen, Carsten Daubjerg, and Asbjørn Sonne Nørgaard for their critical and encouraging comments. Paula Blomqvist, Anders Håkansson, Anders Lindbom, and Urban Lundberg have been most helpful in my search for material on the Swedish case and supplied excellent criticism of earlier versions of the paper. Thanks are also due to Joakim Palme for providing me with material from the recent Swedish welfare commission and to Christian Bertelsen, Jacob Christensen, Jonah Levy, Adam Sheingate, and Kutsal Yesilkagit for helpful comments. Finally, thanks to Lone Winther for help in preparing the manuscript.

\section{NOTES}

1. A few scholars discussing the Swedish experience have actually pointed to the role of the Swedish Social Democrats (Pierre; Premfors 1998; see also Schwartz).

2. Thanks to Carsten Daubjerg for suggesting that the concepts of historical institutionalism could clarify my argument on this point.

3. In Denmark, however, extensive user fees exist for dental care and paying for prescription drugs. These areas are not included in the following analysis.

4. In Denmark, independent institutions have long played a role in elderly care. In principle, these institutions are private; in reality, they are integrated into the public sector and do not constitute an element of competition (Bertelsen 2000, 77-80).

5. In terms of the number of people cared for, contracting out is the more important of these two kinds of care-covering 80 percent of the elderly cared for by private providers-and is the kind that is increasing (Socialstyrelsen 1999b, 40).

6. These private persons are employed and supervised by the municipalities. Thus, there is no element of private competition involved. As with care for the elderly, Denmark has a tradition of independent institutions in child care. However, apart from different pedagogical principles in some of these independent institutions, they hardly differ at all from public institutions and do not constitute an element of competition (BUPL 2000).

7. These figures can be interpreted as measuring both output and outcome. Whether pool schemes are established depends on whether the municipalities will allow them as well as on initiatives from parents.

8. As above, this figure can be interpreted as measuring both output and outcome.

9. Other differences between the two countries include the fact that the Swedish school system has historically been much more centralized and that user boards, which have been mandatory in Denmark since 1970, have never existed in Sweden (Lindbom 1995). 
10. The number of children attending private schools in Denmark has been increasing, from 8.9 percent in the mid-1980s (Christensen 2000, 210) to 12 percent in 1999 (Dannmarks Statistik 2000:10). In Sweden, the number had increased to 3.4 percent by 1999 (Skolverket 2000b, 88). However, these figures measure outcome.

11. The recent working program of the SAP (Socialdemokraterne i Sverige, 17) states that "alternative forms of service delivery such as co-operatives ... should be further developed." This formulation should probably be interpreted as stating that the party would prefer co-operatives instead of profit-maximizing firms as competitors to public delivery. The SAP is not enthusiastic about competition from private firms, but does not seem to directly oppose it.

\section{REFERENCES}

Albæk, Erik, Lawrence Rose, Lars Strömberg, and Krister Ståhlberg, eds. 1996. Nordic Local Government. Helsinki: The Association of Finnish Local Authorities.

Anell, Anders. 1996. The Monopolistic Integrated Model and Health Care Reform: The Swedish Experience. Health Policy 37:19-33.

Anell, Anders, and Patrick Svarvar. 1995. Ekonomiska styrformer i hälsooch sjukvärden: utvecklingslinjer och lärdomar för framtiden [Economic Control in the Health-Care Sector: Prospects for Development and Future Learning]. In Den planerade marknaden [The Planned Market]. Stockholm: Socialstyrelsen.

Antman, Peter. 1994. Vägen til systemskiftet—den offentlige sektorn [The Path to a Change of System-The Public Sector]. In Rolf Å. Gustafsson, ed., Köp och sälj, var god svälj? [untranslatable]. Stockholm: Arbetsmiljöfonden.

Barlow, John, David Farnham, Sylvia Horton, and F. F. Ridley. 1996. Comparing Public Managers. In David Farnham, Sylvia Horton, John Barlow, and Annie Hondeghem, eds., New Public Managers in Europe. London: Macmillan.

Baumgartner, Frank R., and Bryan D. Jones. 1993. Agendas and Instabilities in American Politics. Chicago: University of Chicago Press.

Bertelsen, Christian. 2000. Politikernes kontroldilemma [Politicians' Governing Dilemma]. Copenhagen: Akademisk Forlag.

- 2001. Forklaringer på kommunal udlicitering i teori og praksis [Explaining Local Contracting-Out in Theory and Praxis]. Nordisk Administrativt Tidsskrift [Nordic Administrative Journal] 1:41-65.

Bille, Lars. 1999. Politisk kronik 2. halvår 1998 [Political Chronicle for the Second Half of 1998]. Økonomi og Politik [Economics and Politics] 72:54-65.

Blom-Hansen, Jens, and Thomas Pallesen. 2001. The Fiscal Manipulation of a Decentralized Public Sector: Macroeconomic Policy in Denmark. Environment and Planning C Government and Policy 19:607-623.

Blomqvist, Paula. 2000. "Ideas and Policy Convergence: Health Care Reform in the Netherlands and Sweden in the 1990s." Paper prepared for the Twelfth International Conference of Europeanists, March 30-April 1, Chicago.

Blomqvist, Paula, and Bo Rothstein. 2000. Välfädsstatens nya ansikte. Demokrati och marknadsreformer inom den offentliga sektorn [The New Face of the Welfare State: Democracy and the Market Reform in the Public Sector]. Stockholm: Agora.

Borchorst, Anette. 2000. Den danske børnepasningsmodel-kontinuitet og forandring [The Danish Child Care Model-Continuity and Change]. Arbejderhistorie [Working-Class History] 4:55-69.

Boréus, Kristina. 1997. The Shift to the Right: Neoliberalism in Argumentation and 
Language in the Swedish Public Debate since 1969. European Journal of Political Research 31:257-286.

Børne- og Ungdomspædagogers Landsforbund (BUPL). 2000. En redegørelse om udlicitering af daginstitutioner [A Review of Contracting Out within the Sector of Daycare Centers]. Copenhagen: BUPL.

Budge, Ian, and Dennis Farlie. 1983. Party Competition-Selective Emphasis or Direct Confrontation? An Alternative View with Data. In Hans Daalder and Peter Mair, eds., West European Party Systems: Continuity and Change. London: Sage Publications.

Castles, Francis G., Rolf Gerritsen, and Jack Vowles, eds. 1996. The Great Experiment: Labour Parties and Public Policy Transformation in Australia and New Zealand. Sidney: Allen and Unwin.

Christensen, Jørgen G. 1991. Den usynlige stat [The Invisible State]. Copenhagen: Gyldendal.

-2000. Governance and Devolution in the Danish School System. In Margaret A. Arnott and Charles D. Raab, eds., The Governance of Schooling: Comparative Studies of Devolved Management. London: Routledge/Falmer.

Christensen, Jørgen G., and Thomas Pallesen. 2001. Institutions, Distributional Concerns, and Public Sector Reforms. European Journal of Political Research 39:179-202.

- Forthcoming. The Political Benefits of Corporatization and Privatization, Journal of Public Policy.

Christiansen, Peter M. 1998. A Prescription Rejected: Market Solutions to Problems of Public Sector Governance. Governance 11:273-295.

Christoffersen, Henrik, and Martin Paldam. Forthcoming. Markets and Municipalities. A Study of the Behavior of the Danish Municipalities. Public Choice.

Clark, David. 2000. Public Service Reform: A Comparative West European Perspective. West European Politics 23:25-44.

Clayton, Richard, and Jonas Pontusson. 1998. Welfare State Retrenchment Revisited: Entitlements Cuts, Public Sector Restructuring, and Egalitarian Trends in Advanced Capitalist Societies. World Politics 51:67-98.

Damgaard, Jens B. 1997. How and Why Bureaucrats Control their Governance Structure. Scandinavian Political Studies 20:243-264.

-1998. Styring og effektivitet: Organisering af dansk børnepasning [Control and Efficiency: Organizing Danish Childcare]. Århus: Politica.

Danmarks Statistik. 1997. Statistiske efterretninger: Social Sikring og Retsvæsen [Statistical Information: Social Security and Administration of Justice] 5. Copenhagen: Danmarks Statistik.

- 2000a. Statistiske efterretninger: Social Sikring og Retsvæsen [Statistical Information: Social Security and Administration of Justice] 12. Copenhagen: Danmarks Statistik.

- 2000b. Statistiske efterretninger: Uddannelse og kultur [Statistical Information: Education and Culture] 10. Copenhagen: Danmarks Statistik.

Denemark, Davic. 1990. Social Democracy and the Politics of Crisis in New Zealand, Britain, and Sweden. In Martin Holland and Jonathan Boston, eds., The Fourth Labour Government. Auckland: Oxford University Press.

Det Kommunale Kartel Organisationsafdelingen. 1999. Udlicitering på ældreområde [Contracting Out within Care for the Elderly]. Copenhagen: Det Kommunale Kartel. Information available online at $\langle$ http://www.dkk.dk $\rangle$.

Diderichsen, Finn. 1995. Market Reforms in Health Care and Sustainability of the Welfare State: Lessons from Sweden. Health Policy 32:141-153.

Dyremose, Henning. 1999. Privatisering-historien om en borgerlig holdningsændring [Privatization: The Story of a Bourgeois Change of Mind]. In Torben Rechendorff and Lars Kjølbye, eds., P.S. Festskrift til Poul Schlüter [P.S.: Essays in Honor of Poul Schlüter]. Copenhagen: Aschehoug. 
Esping-Andersen, Gøsta. 1990. Three Worlds of Welfare Capitalism. Cambridge, U.K.: Polity Press.

1999. Social Foundations of Postindustrial Economies. Oxford: Oxford University Press.

Farnham, David, Sylvia Horton, John Barlow, and Annie Hondeghem, eds. 1996. New Public Managers in Europe. London: Macmillan.

Flynn, Norman, and Franz Strehl, eds. 1996. Public Sector Management in Europe. London: Prentice Hall and Harvester Wheatsheaf.

Giamo, Susan, and Phillip Manow. 1999. Adapting the Welfare State: The Case of Health Care Reform in Britain, Germany, and the United States. Comparative Political Studies 32:967-1000.

Green-Pedersen, Christoffer. 2000. How Politics Still Matters: Retrenchment of Old-Age Pensions, Unemployment Benefits, and Disability Pensions/Early Retirement Benefits in Denmark and in the Netherlands from 1982 to 1998. Ph.D. dissertation, Department of Political Science, University of Århus.

- 2001. Welfare State Retrenchment in Denmark and the Netherlands, 1982-1998: The Role of Party Competition and Party Consensus. Comparative Political Studies 34:963-985.

Greve, Carsten. 1997. Fra ideologi til pragmatisme? Træk af forvaltningspolitikken for privatisering i Danmark 1983-1996 [From Ideology to Pragmatism? Administration Politics for Privatization in Denmark 1983-1996, in Outline]. In Carsten Greve, ed., Privatisering, selskabsdannelser og udlicitering [Privatization, Corporatization, and Contracting Out]. Århus: Systime.

Gustafsson, Lennart. 1987. Renewal of the Public Sector in Sweden. Public Administration 65:179-191.

Hadenius, Stig, and Lennart Nilsson. 1991. Ifrågasatt: Offentliga sektorn i debatt och opinion [Questioning the Public Sector: Debate and Opinion]. Stockholm: Svensk Informations Mediecenter.

Håkansson, Anders. 1997. Nittiotalets förändringsvåg [Changes in the 1990s]. In Anders Håkansson, ed., Folket och Kommunerna: Systemskiftet som kom av sig [The People and the Municipalities: The Change of System that Came About]. Stockholm: Stockholms Universitet, Statsvetenskapliga institutionen.

Hansen, Karin. 2001. Local Councilors: Between Local Government and Local Governance. Public Administration 79:105-123.

Hemerijck, Anton, and Martin Schludi. 2000. Sequences of Policy Failures and Effective Policy Responses. In Fritz W. Scharpf and Vivien A. Schmidt, eds., Welfare and Work in the Open Economy. Vol. 1, From Vulnerability to Competitiveness. Oxford: Oxford University Press.

Hood, Christopher. 1991. A Public Management for All Seasons. Public Administration 69:3-19.

.1996. Exploring Variations in Public Management Reforms of the 1990s. In Hans A. G. M. Bekke, James L. Perry, and Theo A. Toonen, eds., Civil Service Systems in Comparative Perspective. Bloomington: Indiana University Press.

Huber, Evelyne, and John D. Stephens. 2000. Partisan Governance, Women's Employment, and the Social Democratic Service State. American Sociological Review 65:323-342.

-2001. Development and Crisis of the Welfare States: Parties and Policies in Global Markets. Chicago: University of Chicago Press.

Institut for Serviceudvikling. 1999. Udlicitering på xldreområdet-Erfaringer fra Sverige og barrierer i Danmark [Contracting Out of Care for the Elderly]. Odense: Institut for Serviceudvikling.

Jespersen, Peter K. 2001. New Public Management reformer i det danske sygehusfelt [New Public Management within the Danish Health-Care Sector]. Nordisk Administrativt Tidsskrift [Nordic Administrative Journal] 1:22-40. 
Kickert, Walter J. M., ed. 1997. Public Management and Administrative Reforms in Western Europe. Cheltenham: Edward Elgar.

Kitschelt, Herbert. 2001. Partisan Competition and Welfare State Retrenchment: When Do Politicians Choose Unpopular Policies? In Paul Pierson, ed., The New Politics of the Welfare State. Oxford: Oxford University Press.

Knudsen, Tim, and Bo Rothstein. 1994. State-Building in Scandinavia. Comparative Politics 26:203-220.

KommunAktuellt Dirkekt-16/9. 1999. Privat äldrevård klyver partierna [Private Care for the Elderly Divides the Political Parties]. Accessed online at 〈http://www.kommunaktuellt.com/arkiv/enkat/entreprenad.htm〉; document no longer available.

Kommunernes Landsforening. 2001. Udbud og udlicitering i kommunerne [Tenders and Contracting Out in the Municipalities]. Copenhagen: Kommunernes Landsforening.

Kristensen, Ole P. 1987. Alliancer og konflikter i forbindelse med privatisering [Alliances and Conflicts with Privatization]. Paper presented at seminar on privatization hosted by Forskningsstiftelsen Fafo, 7-8 October, Oslo.

-1988. The Politics of Privatization: The Case of Denmark. Paper presented at the European Consortium of Political Research, Joint Sessions of Workshops, April 5-10, Remini.

Lane, Jan-Erik. 1996. Reform in the Nordic Countries. In Jan-Erik Lane, ed., Public Sector Reform. London: Sage.

Lehto, Juhani, Nina Moss, and Tina Rostgaard. 1999. Universal Public Social Care and Health Services? In Mikko Kautto, Matti Heikkila, Bjørn Hvinden, Stafan Marklund, and Niels Ploug, eds., Nordic Social Policy. London: Routledge.

Lidström, Anders. 1999. Local School Choice Policies in Sweden. Scandinavian Political Studies 22:137-156.

Lidström, Anders, and Christine Hudson. 1995. Skola i förändring: Decentralisering och lokal varition [Schools in Change: Decentralization and Local Variation]. Stockholm: Nerenius and Santérus Förlag.

Lindbom, Anders. 1995. Medborgarskapet i välfärdsstaten: Foräldrainflytande i skandinavisk grundskola [Citizenship in the Welfare State: Parents' Say in Scandinavian Compulsory Schools]. Stockholm: Almqvist and Wiksell International.

-1998. Institutional Legacies and the Role of Citizens in the Scandinavian Welfare State. Scandinavian Political Studies 21:109-128.

Loughlin, John, and Guy B. Peters. 1997. State Traditions, Administrative Reforms, and Regionalization. In Michael Keating and John Loughlin, eds., The Political Economy of Regionalism. London: Frank Cass.

Montin, Stig. 1992. Privatiseringsprocesseri kommunerna-teoretiska utgångspunkter och empiriska exempel [Privatization Processes in the MunicipalitiesTheoretical Starting Points and Empirical Examples]. Statsvetenskaplig Tidsskrift [Political Science Journal] 95:31-57.

_.1997. New Public Management på svenska [New Public Management in Sweden]. Politica 29:262-278.

Montin, Stig, and Ingemar Elander. 1995. Citizenship, Consumerism, and Local Government in Sweden. Scandinavian Political Studies 18:25-51.

Nannestad, Peter, and Christoffer Green-Pedersen. Forthcoming. Keep the Bumblebee Flying: Economic Policy in the Welfare State of Denmark, 1973-1999. In Erik Albæk, Leslie C. Eliason, Asbjørn S. Nørgaard, and Herman Schwartz, eds., Managing the Danish Welfare State under Pressure: Towards a Theory of the Dilemmas of the Welfare State. Århus: Århus University Press.

OECD. 1993. Managing with Market-Type Mechanisms. Paris: OECD/PUMA.

Olsen, Johan P., and B. Guy Peters. 1996. Learning from Experience? In Johan P. Olsen and B. Guy Peters, eds., Lessons from Experience. Oslo: Scandinavian University Press. 
Pallesen, Thomas. 1997. Health Care Reforms in Britain and Denmark: The Politics of Economic Success and Failure. Århus: Politica.

Pallesen, Thomas, and Lars D. Pedersen. Forthcoming. Health Care in Denmark. Adapting to Cost Containment in the 1980s. In Erik Albæk, Leslie C. Eliason, Asbjørn S. Nørgaard, and Herman Schwartz, eds., Managing the Danish Welfare State under Pressure: Towards a Theory of the Dilemmas of the Welfare State. Arrhus: Århus University Press.

Peters, B. Guy. 1997. Policy Transfers between Governments: The Case of Administrative Reforms. West European Politics 20:71-88.

Pierre, Jon. 1993. Legitimacy, Institutional Change, and the Politics of Public Administration in Sweden. International Political Science Review 14:387-401.

Pierson, Paul. 1994. Dismantling the Welfare State: Reagan, Thatcher, and the Politics of Retrenchment. Cambridge, U.K.: Cambridge University Press.

.1996. The New Politics of the Welfare State. World Politics 48:143-179.

2000. Increasing Returns, Path Dependence, and the Study of Politics. American Political Science Review 94:251-267.

Pollitt, Christopher, and Geert Bouckaert. 2000. Public Management Reform: A Comparative Analysis. Oxford: Oxford Univeristy Press.

Pollitt, Christopher, and Hilkka Summa. 1997. Trajectories of Reform: Public Management Change in Four Countries. Public Money and Management 17:7-18.

Premfors, Rune. 1991. The "Swedish Model" and Public Sector Reform. West European Politics 14:83-95.

-1998. Reshaping the Democratic State: Swedish Experience in a Comparative Perspective. Public Administration 76:142-159.

Rehnberg, Claus. 1997. Sweden. In Chris Ham, ed., Health Care Reform: Learning from International Experience. Buckingham: Open University Press.

Rhodes, Rod A. W. 1999. Traditions and Public Sector Reform: Comparing Britain and Denmark. Scandinavian Political Studies 22:341-370.

Riker, William. 1986. The Art of Political Manipulation. New Haven, CT: Yale University Press.

Ross, Fiona. 2000a. Beyond Left and Right: The New Partisan Politics of Welfare. Governance 13:155-183.

-2000b. Interest and Choice in the Not Quite So New Politics of Welfare. West European Politics 23:11-34.

Rothstein, Bo. 1993. The Crisis of the Swedish Social Democrats and the Future of the Universal Welfare State. Governance 6:492-517.

Sahlin-Andersson, Kerstin. 1999. I mötet mellam reform och praktik [The Clash of Reform and Practice]. In Eva Z. Bentsen, Finn Borum, Guobjörg Erlingsdóttir, and Kerstin Sahlin-Andersson, eds., Når styringsambitioner møder praksis [When Governing Ambitions Meet Practice]. Copenhagen: Handelshøjskolens Forlag.

Saltman, Richard B., and Josep Figueras. 1998. Analyzing the Evidence on European Health Care Reforms. Health Affairs March/April:85-108.

Scharpf, Fritz W., and Vivien A. Schmidt, eds. 2000. Welfare and Work in the Open Economy. Oxford: Oxford University Press.

Schüllerqvist, Ulf. 1995. Förskjutningen av svensk skolpolitisk debatt under det senaste decenniet [The Shift of the Swedish Political Debate on Schools during the Past Decade]. In Tomas Englund, ed., Utbildningspolitiskt systemskifte? [An Educational Political Change of System?]. Stockholm: HLS Forlag.

Schwartz, Herman. 1994. Small States in Big Trouble. State Reorganization in Australia, Denmark, New Zealand, and Sweden in the 1980s. World Politics 46:527-555.

Sheingate, Adam. 2000. Agricultural Retrenchment Revisited: Issue Definition and Venue Change in the United States and European Union. Governance 13:335-363. 
Skolverket. 2000a. Barnomsorg och skola i siffror 2000: Del 2-Barn, personel, elever och lärare [Child Care and Schools in Numbers, 2000: Part 2-Children, Personnel, Students, and Teachers]. Stockholm: Skolverket.

-2000b. Beskrivande data om barnomsorg och skola 2000: Rapport 192 [Information on Child Care and Schools in Numbers, 2000: Report 192]. Stockholm: Skolverket.

Social Services Act. 1997. Law 229. Proceedings of the Danish Folketing, 19961997.

Socialdemokraterne i Sverige. 2000. Socialdemokraternas riktlinjer för utveckling och jämlikhet [Social Democratic Guidelines for Development and Equality]. Stockholm: Socialdemokraterne i Sverige.

Socialdemokratiet i Danmark. 1996. Socialdemokratiets arbejdsprogram 19962000 [The Social Democratic Working Plan 1996-2000]. Copenhagen: Socialdemokratiet i Danmark.

Socialstyrelsen. 1999a. Fyra underlagsrapporter til kommittén för Välfärdbokslut över 1990-tallet [Four Basic Reports to the Committee for Welfare Balance of the 1990s]. Stockholm: Socialstyrelsen.

—.1999b. Konkurrensutsättning och entreprenader inom äldreomsorgen [Competition and Contracting Out in Elderly Care]. Stockholm: Socialstyrelsen.

SOU. 2000:3. Delbokslut: Välfärd under 1990-talet-en sammenfatning [Preliminary Balance: Welfare During the 1990s-A Summary]. Stockholm.

Svensson, Helene, and Sara Nordling. 1995. Effekter av nya ekonomiska styrformer-en litteraturöversikt [Effects of New Economic Forms of Control-The Literature in Outline]. In Den planerade marknaden [The Planned Market]. Stockholm: Socialstyrelsen.

Svensson, Torsten. 2001. Marknadsanpassningens Politik [Market Adjustment Politics]. Uppsala: Statsvetenskapeliga Institutionen .

Szebehely, Marta. 2000. Âldreomsorg i förandring-knappare resurser och nya organisationsformer [Elderly Care in Change-Limited Resources and New Forms of Organization]. In SOU 2000:39. Stockholm: Fritze.

Timonen, Virpi. 2001. What Explains Public Service Restructuring? Evaluating Contending Explanations. Journal of European Public Policy 8:43-59.

Vrangbæk, Karsten. 1999. New Public Management i sygehusfeltet-udformning og konsekvenser [New Public Management in the Health Care Sector-Implementation and Consequences]. In Eva Z. Bentsen, Finn Borum, Guobjörg Erlingsdóttir, and Kerstin Sahlin-Andersson, eds., Når styringsambitioner møder praksis [When Governing Ambitions Meet Practice]. Copenhagen: Handelshøjskolens Forlag.

-2000. Forandringer i sygehussektoren som følge af frit sygehusvalg [Changes in the Health-Care Sector as a Result of Free Choice of Hospital]. In Marianne Antonsen and Torben Beck Jørgensen, eds., Forandringer $i$ teori og praksis [Changes in Theory and Praxis]. Copenhagen: DJØFs Forlag.

Weaver, R. Kent. 1986. The Politics of Blame Avoidance. Journal of Public Policy 6:371-398.

Wright, Vincent. 1994. Reshaping the State: The Implications for Public Administration. West European Politics 17:102-137.

Yesilkagit, Kutsal, and Jouke de Vries. Forthcoming. Core Executives, Institutions, and Public Sector Reform in New Zealand and the Netherlands. Public Administration. 